RESEARCH PAPER RP1140

Part of Journal of Research of the National Bureau of Standards, Volume 21, October 1938

\title{
HEATS OF COMBUSTION OF DIAMOND AND OF GRAPHITE
}

\author{
By Ralph S. Jessup
}

\section{ABSTRACT}

Measurements were made of the heats of combustion of one artificial graphite, two natural graphites, and two samples of diamond. The bomb calorimeter used was calibrated electrically and by means of benzoic acid. The amount of reaction in each combustion experiment was determined from the mass of carbon dioxide formed. This method of determining the amount of reaction automatically eliminates the effect of unburned carbon and of some impurities. It was found, however, that results for different samples did not agree unless the samples were purified. Two methods of purification were used: (a) heating in vacuo to $1,800^{\circ}$ $\mathrm{C}$ and (b) treatment with hydrochloric and hydrofluoric acids and subsequent heating in vacuo to $200^{\circ} \mathrm{C}$ to remove traces of the acids. Both methods yielded graphite containing only small amounts of impurities. The mean value obtained for the heat of combustion $(-\Delta H)$ of the purified graphites in oxygen at $25^{\circ} \mathrm{C}$ and a constant pressure of 1 atmosphere to form gaseous carbon dioxide at the same temperature and pressure was 393.396 international kilojoules per mole $\left(44.010 \mathrm{~g}\right.$ of $\left.\mathrm{CO}_{2}\right)$. The maximum deviation of the mean value for any one of the purified samples from this value was 0.021 percent.

The two samples of diamond, purified by treatment with aqueous hydrochloric and hydrofluoric acids and subsequently heated in vacuo to about $570^{\circ} \mathrm{C}$, had average particle sizes of $2.5 \mu$ and $39.5 \mu$, respectively, and yielded the following respective mean values for the heat of combustion $(-\Delta H)$ at $25^{\circ} \mathrm{C}$ and 1 atmosphere, in oxygen to form gaseous carbon dioxide: 395.771 and 395.287 international kilojoules per mole. The difference between the two values, which is several times the estimated uncertainty of the measurements, is in proper direction to be accounted for on the basis of particle size, but the first sample appears to be not fine enough to account quantitatively for the difference.

\section{CONTENTS}

I. Introduction

II. Apparatus and methods

III. Calibration of calorimeter

IV. Measurements of heats of combustion 481

1. Material _... 481

2. Ceylon natural graphite 482

3. Buckingham natural graphite

4. Artificial graphite. 485

5. Résumé of results on purified graphite 486

6. Diamond. 487

V. References

\section{INTRODUCTION}

The work described in this paper is part of a joint investigation by the National Bureau of Standards and the Coal Research Laboratory of the Carnegie Institute of Technology in Pittsburgh. When this 
work was begun the only published measurements of the heats of combustion of the various forms of carbon which approach modern requirements as to accuracy were those of Roth and his coworkers $[10,11,12] .{ }^{1}$ Since Roth's measurements were made there have been improvements in the experimental technique of heat-of-combustion measurements and in the interpretation of bomb calorimetric data, which made a new investigation of the heat of combustion of carbon desirable.

That part of the work which was done at the Coal Research Laboratory of the Carnegie Institute of Technology is described by Dewey and Harper [2] in the preceding paper in this Journal. It will be seen from their paper that their results on three natural graphites and two samples of an artificial graphite are in excellent agreement, but that their value for Ceylon natural graphite is lower by about 0.2 percent than the mean of their values for the other graphites.

The present work was originally intended to include measurements of the heat of combustion of diamond only. However, at the suggestion of Dr. Lowry, Director of the Coal Research Laboratory, measurements were also made on three of the graphites on which measurements had been made by Dewey and Harper, namely, artificial graphite and Ceylon and Buckingham natural graphites, partly in the hope of finding the cause of their lower value for Ceylon natural graphite and partly for the purpose of obtaining the difference between the heats of combustion of graphite and diamond from measurements made in the same laboratory.

\section{APPARATUS AND METHODS}

The apparatus, experimental procedure, and methods of calculating results have been described in detail previously [3,6], so that only a brief description will be given here.

The measurements were made by means of a calorimeter which is essentially the same as that described by Dickinson [3]. The method of measurement consisted in comparing the rise in temperature of the calorimetric system produced by a measured quantity of energy, with the rise in temperature of the same calorimetric system over approximately the same temperature interval produced by the combustion of a sample of carbon in the bomb. The amount of reaction in each experiment was measured by absorbing the resulting carbon dioxide in Ascarite (a sodium hydroxide-asbestos mixture) and weighing [5, 8], using for the atomic weights of carbon and oxygen the values 12.010 and 16.0000 , respectively. The glass-stoppered U-tubes containing the Ascarite were filled with hydrogen for weighing, both before and after absorption of the carbon dioxide, in order to minimize the error resulting from uncertainty in the change in volume of the Ascarite upon absorption of carbon dioxide [8].

Usually a small quantity of carbon monoxide was formed in the bomb, amounting on the average to about 0.01 percent of the carbon dioxide formed. The quantity of carbon monoxide formed in each experiment was determined by passing the gas from the bomb, after absorption of the carbon dioxide, through a copper tube heated to redness, absorbing the resulting carbon dioxide in Ascarite and weighing.

\footnotetext{
1 Numbers in brackets indicate the literature references given at the end of this paper.
} 
Before heating the copper tube for the purpose of oxidizing the carbon monoxide, the absorption train was always flushed with oxygen from the supply tank. However, there is a possibility that some water vapor might be formed by oxidation of hydrogen adsorbed on the copper or copper oxide in the copper tube, or of hydrogen present as a result of incomplete flushing of the absorption train. Consequently, a drying tube was placed between the copper tube and the U-tube containing the Ascarite.

It was possible to close the bomb and its valve tightly enough so that there was no perceptible leakage of gas either before or after a combustion experiment. It was found, however, that during the combustion there was always a slight leakage of gas. The amount of gas which leaked out was determined in each experiment by means of the arrangement shown in figure 1 . The inverted graduated glass tube $T$, was initially filled with water, and the gas which leaked out either through the valve or past the gold gasket, $G$ (1 mm wide), was caught in the tube, and its volume observed at the end of the experiment. The bomb threads and the bearing surface, $S$, were lubricated with vaseline, which also prevented water

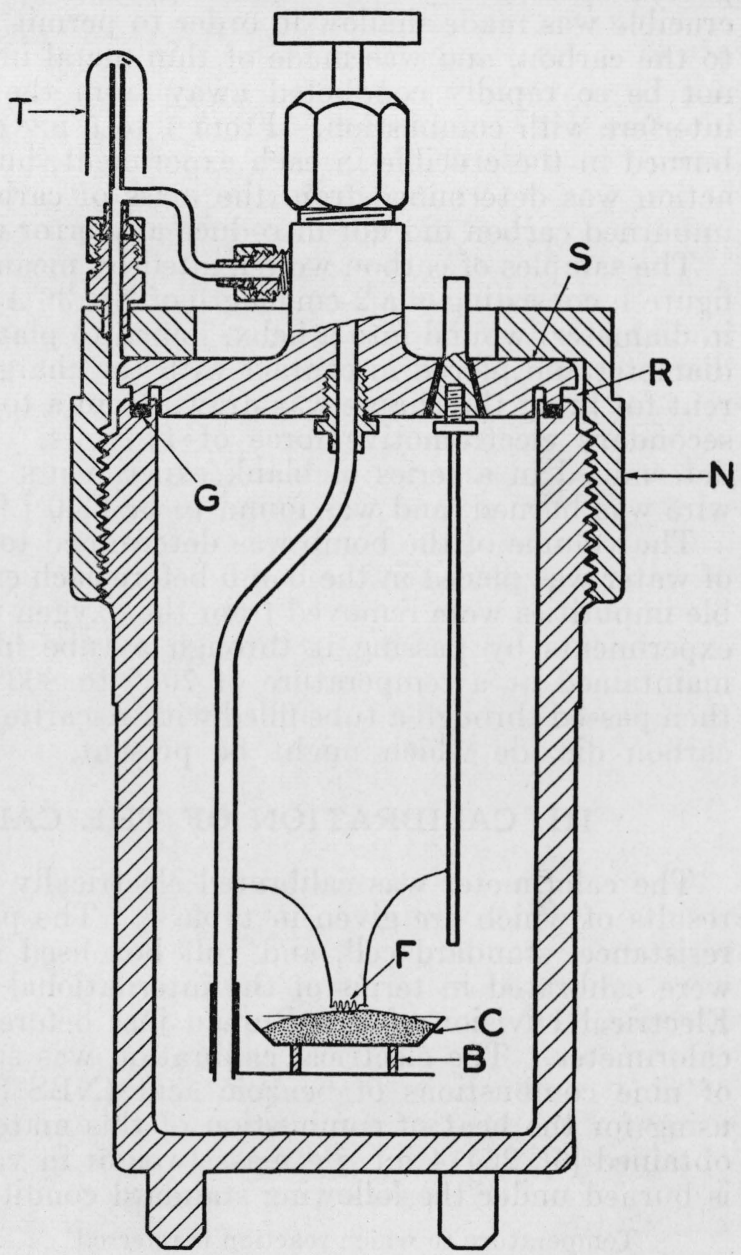

Figure 1.-Schematic drawing of bomb.

$T$, graduated glass tube for measuring gas leakage; $N$, bomb nut; $G$, gold washer; $S$, surface between bomb nut and bomb cover; $R$, annular space between bomb and nut; $F$, electric fuse of iron wire; $C$, platinum crucible; $B$, beryllium oxide ring.

from seeping into the space, $R$, and displacing the air initially present in this space. The vaseline was carefully removed after each experiment and a weighed amount $(0.4 \mathrm{~g})$ was placed on the threads and the surface, $S$, of the bomb nut, $N$, before the next experiment. The volume of gas which leaked out during an experiment amounted usually to 0.002 or 0.003 percent of the total quantity of gas in the 
bomb. Since the concentration of carbon dioxide in the valve and in the vicinity of the washer, $G$ (fig. 1 ), was probably very small at the time the leakage occurred, the observed mass of carbon dioxide was not corrected for the leakage.

The samples of about $1 \mathrm{~g}$ of carbon were burned in a shallow crucible, $C$, made of sheet platinum about $0.05 \mathrm{~mm}$ thick, which was supported upon a beryllium oxide ring, $B$, as shown in figure 1. The crucible was made shallow in order to permit ready access of oxygen to the carbon, and was made of thin metal in order that heat might not be so rapidly conducted away from the burning carbon as to interfere with combustion. From 1 to $5 \mathrm{mg}$ of carbon was left unburned in the crucible in each experiment, but as the amount of reaction was determined from the mass of carbon dioxide formed the unburned carbon did not introduce any error into the measurements.

The samples of carbon were ignited by means of an electric fuse, $F$, figure 1, consisting of a 2-cm length of No. 36 AWG iron wire $(0.13 \mathrm{~mm}$ in diameter) wound into a helix, joined to platinum leads $0.25 \mathrm{~mm}$ in diameter and placed in contact with the charge of carbon. The current for firing the charge was drawn from a toy transformer having a secondary electromotive force of 14 volts. The firing energy was determined in a series of blank experiments in which only the iron wire was burned, and was found to be $23.0 \mathrm{j}$ [6].

The volume of the bomb was determined to be $377 \mathrm{~cm}^{3}$. One $\mathrm{cm}^{3}$ of water was placed in the bomb before each experiment. Combustible impurities were removed from the oxygen used in the combustion experiments by passing it through a tube filled with copper oxide maintained at a temperature of $700^{\circ}$ to $800^{\circ} \mathrm{C}$. The oxygen was then passed through a tube filled with Ascarite in order to remove any carbon dioxide which might be present.

\section{CALIBRATION OF THE CALORIMETER}

The calorimeter was calibrated electrically in 14 experiments, the results of which are given in table 1 . The potentiometer, standard resistance, standard cell, and volt box used in these measurements were calibrated in terms of the international electrical units by the Electrical Division of this Bureau just before the calibration of the calorimeter. The electrical calibration was supplemented by means of nine combustions of benzoic acid (NBS Standard Sample 39e), using for the heat of combustion of this material the value recently obtained [6], 26414 int. $\mathrm{j} / \mathrm{g}$ mass (weight in vacuo) when the sample is burned under the following standard conditions:

Temperature to which reaction is referred $30^{\circ} \mathrm{C}$.

Initial oxygen pressure in bomb at $30^{\circ} \mathrm{C} \ldots \ldots$ atm.

Mass of water placed in bomb per liter of bomb volume... $3 \mathrm{~g}$.

Mass of benzoic acid burned per liter of bomb volume..- $\quad 3 \mathrm{~g}$.

The results of the calibration by means of benzoic acid are given in table 2, and the mean of these results is seen to be in agreement within 0.008 percent with the mean of the results of the electrical calibration given in table 1 . 
TABLE 1.-Results of electrical calibration of calorimeter

\begin{tabular}{|c|c|c|c|}
\hline Experiment & \multirow{2}{*}{$\begin{array}{c}\begin{array}{c}\text { Energy } \\
\text { equivalent } \\
\text { at } 28.5^{\circ} \mathrm{C}\end{array} \\
\text { Int. } j /^{\circ} \mathrm{C} \\
13498.6 \\
13497.0 \\
13495.9 \\
13496.0 \\
13496.8\end{array}$} & \multicolumn{2}{|c|}{ Deviation from mean } \\
\hline $\begin{array}{l}1 \\
2 \\
3 \\
4 \\
5 \\
-\end{array}$ & & $\begin{array}{c}\text { Int } j /^{\circ} C \\
+0.1 \\
-1.5 \\
-2.6 \\
-2.5 \\
-1.7\end{array}$ & $\begin{array}{r}\text { Percent } \\
+0.001 \\
-.011 \\
-.019 \\
-.019 \\
-.013\end{array}$ \\
\hline $\begin{array}{l}6 \\
7 \\
8 \\
9 \\
10\end{array}$ & $\begin{array}{l}13496.4 \\
13503.4 \\
13502.8 \\
13500.4 \\
13500.6\end{array}$ & $\begin{array}{l}-2.1 \\
+4.9 \\
+4.3 \\
+1.9 \\
+2.1\end{array}$ & $\begin{array}{r}-.016 \\
+.036 \\
+.032 \\
+.014 \\
+.016\end{array}$ \\
\hline 11 12 & $\begin{array}{l}13495.5 \\
13499.7 \\
13499.7 \\
13495.4\end{array}$ & $\begin{array}{l}-3.0 \\
+1.2 \\
+1.2 \\
-2.8\end{array}$ & $\begin{array}{r}-.022 \\
+.009 \\
+.009 \\
-.021\end{array}$ \\
\hline Mean.- & 13498.5 & \pm 2.3 & \pm .017 \\
\hline
\end{tabular}

TABLE 2.-Results of benzoic acid calibration of calorimeter

\begin{tabular}{|c|c|c|c|}
\hline Experiment & $\begin{array}{c}\text { Energy } \\
\text { equivalent } \\
\text { at } 28.5^{\circ} \mathrm{C}\end{array}$ & \multicolumn{2}{|c|}{ Deviation from mean } \\
\hline $\begin{array}{l}1 \\
2 \\
3 \\
4 \\
5\end{array}$ & $\begin{array}{c}\text { Int. } j /^{\circ} C \\
13498.5 \\
13490.2 \\
13500.1 \\
13495.4 \\
13499.8\end{array}$ & $\begin{array}{c}\text { Int. }\left.j\right|^{\circ} C \\
-1.1 \\
-9.4 \\
+0.5 \\
-4.2 \\
+0.2\end{array}$ & $\begin{array}{r}\text { Percent } \\
-0.008 \\
-.070 \\
+.004 \\
-.031 \\
+.002\end{array}$ \\
\hline $\begin{array}{l}6 \ldots \\
7 \ldots \ldots \\
8 \ldots \ldots \\
9 \ldots \ldots\end{array}$ & $\begin{array}{l}13501.6 \\
13501.2 \\
13510.3 \\
13499.5\end{array}$ & $\begin{array}{r}+2.0 \\
+1.6 \\
+10.7 \\
-0.1\end{array}$ & $\begin{array}{l}+.015 \\
+.012 \\
+.079 \\
-.001\end{array}$ \\
\hline Mean.-. & 13499.6 & \pm 3.3 & \pm 0.025 \\
\hline
\end{tabular}

The mean value for the energy equivalent obtained from the electrical calibration of the calorimeter was used in calculating the results of experiments 1 to 5 , inclusive, on Ceylon graphite (table 7 ). After experiment 5 on Ceylon graphite, an accident to the calorimeter necessitated repairs involving the addition to the calorimeter vessel of $11.9 \mathrm{~g}$ of solder (50 percent of tin, 50 percent of lead), and the removal of $1.3 \mathrm{~g}$ of brass. After the repairs, the weight of water used in the calorimeter was decreased by $30.6 \mathrm{~g}$. These changes involved a change in the energy equivalent of the calorimeter, the calculation of which is shown in table 3. 
TABLE 3.-Change in energy equivalent of calorimeter as a result of repairs

\begin{tabular}{|c|c|c|c|c|}
\hline Material added & $\begin{array}{l}\text { Mass } \\
\text { added }\end{array}$ & $\begin{array}{l}\text { Specific } \\
\text { heat at } \\
28.5^{\circ} \mathrm{C} \text {. }\end{array}$ & $\begin{array}{c}\text { Heat capac- } \\
\text { ity of } \\
\text { material }\end{array}$ & $\begin{array}{l}\text { Authority for spe- } \\
\text { cific-heat value }\end{array}$ \\
\hline $\begin{array}{l}\text { Solder. } \\
\text { Brass } \\
\text { Water }\end{array}$ & $\begin{array}{c}g \\
+11.9 \\
-1.3 \\
-30.63\end{array}$ & $\begin{array}{r}\text { Int. } j / g{ }^{\circ} C \\
0.178 \\
.384 \\
4.173\end{array}$ & $\begin{array}{r}\text { Int. } j /{ }^{\circ} \mathrm{C} \\
+2.12 \\
-0.50 \\
-127.8\end{array}$ & $\begin{array}{l}\text { ICT } \mathbf{5}, 93,94 . \\
\text { ICT } \mathbf{5}, 121 . \\
\text { ICT } \mathbf{5}, 113 .\end{array}$ \\
\hline
\end{tabular}

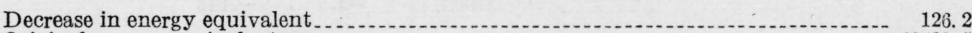

Original energy equivalent

Energy equivalent after repairs ............ 13372.3

The value given in table 3 for the energy equivalent of the calorimeter after repairs was used in the calculation of the results of experiments 6 to 16 , inclusive, on Ceylon graphite (table 7), experiments 1 to 8 , inclusive, on Buckingham graphite (table 8), experiments 1 to 4 , inclusive, on the first sample of artificial graphite (table 9), and experiments 1 to 3 , inclusive, on the second sample of artificial graphite (table 9).

For the remaining experiments a new calorimetric resistance thermometer was used. The calorimeter was calibrated with the new thermometer by means of 12 combustions of benzoic acid (Standard Sample 39e), using for the heat of combustion of this material the value given above. The results of this calibration of the calorimeter are shown in table 4.

TABLE 4.-Results of benzoic acid calibration of calorimeter with new thermometer

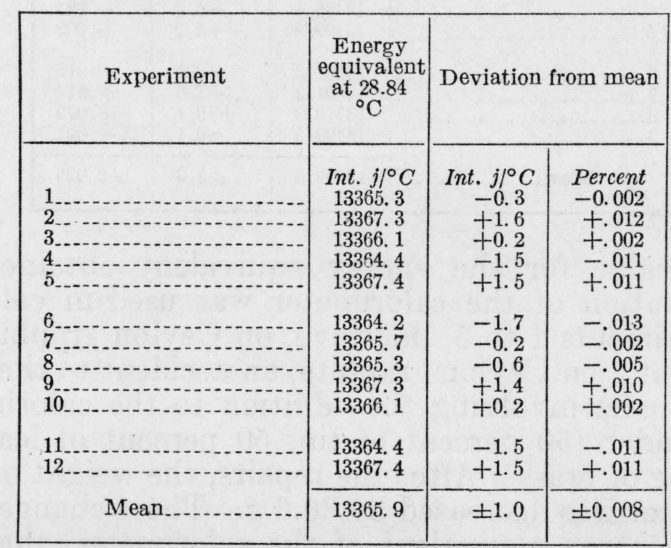

The difference between the mean value of the energy equivalent of the calorimeter given in table 4 and the value given in table 3 was found to be caused by a difference in the temperature intervals defined by the two thermometers under the conditions of the calorimetric experiments. The old thermometer was of an experimental type, and results obtained with it were not quite as precise as those obtained with the new thermometer, which was a calorimetric thermometer of the type which has been used at this Bureau for many years. The difference between the two thermometers did not introduce any systematic error into the measurements of heats of combustion, since 
the value of energy equivalent used in calculating the results of heatof-combustion measurements with either thermometer was the value obtained in the calibration experiments with the same thermometer. In the tabulations of the results of the heat-of-combustion measurements given later in this paper, the values of energy equivalent used for the various experiments are designated by the letters $A, B$, and $C$, preceding the experiment number, where these letters have the following meanings: $A$, mean value of energy equivalent from table 1 ; $B$, value of energy equivalent from table 3 ; and $C$, mean value of energy equivalent from table 4.

\section{MEASUREMENTS OF HEATS OF COMBUSTION}

\section{MATERIAL}

Measurements were made on the three samples of graphite mentioned previously and on two samples of diamond. The first diamond sample was purchased from a diamond grinding establishment in the Netherlands, with the assistance of Prof. P. E. Verkade of the Commercial University in Rotterdam. This sample was in the form of a very fine powder. The size distribution of the particles was measured microscopically ${ }^{2}$ and it was found that the average diameter of the particles was $2.5 \mu$. Average particle diameter is here defined on the basis that if each particle had the average diameter the surface of the powder per gram of diamond would be the same as that of the actual sample. The ash content ${ }^{3}$ of the sample when received was 0.30 percent. Successive treatments of the sample with hydrochloric and hydrofluoric acids ${ }^{4}$ reduced the ash content to 0.05 percent. The second sample of diamond was purchased from a dealer in commercial diamonds in this country. It consisted originally of small pieces, of the order of $1 \mathrm{~mm}$ in diameter, most of which were clear and "water white." Discolored pieces were rejected; the remainder of the sample was ground in a stainless-steel mortar and treated with hydrochloric and hydrofluoric acids, after which the ash content of the sample was found to be 0.02 percent. The average particle size of the second sample of diamond after grinding was $39.5 \mu$. About $2 \mathrm{~g}$ of the second sample was ground to an average particle size of $22.9 \mu$.

The samples of graphite were ground in an agate mortar, and some measurements of heat of combustion were made on each material, without further treatment of the sample. Samples of the two natural graphites were then heated in vacuo in an Acheson graphite crucible by means of an induction furnace to various temperatures, the maximum temperature in each case being about $1,800^{\circ}$ C. ${ }^{5}$ The mercury-vapor pump used in maintaining the vacuum was capable of reducing the pressure to $<10^{-4} \mathrm{~mm}$ of mercury when the samples of graphite were cold, but at the higher temperatures the evolution of gas from the thermal insulating material around the graphite crucible was so great that the pressure could not be reduced below about 0.02 $\mathrm{mm}$. The pump was connected to the vessel inclosing the graphite through a trap immersed in liquid air.

2 The microscopic examination of the two samples of diamond'was made by C. P. Saylor of this Bureau. 3 All ash determinations mentioned in this paper were made by C. J. Rodden of this Bureau.

- The chemical treatment of both samples of diamond and one sample of graphite and the grinding of the second sample of diamond were done by $\mathrm{H}$. B. Knowles of this Bureau.

$\mathrm{SW}$. F. Roeser and A. I. Dahl of this Bureau assisted in heating the samples of graphite and in measurement of the temperatures. 
Spectrochemical analyses ${ }^{6}$ were made on some of the samples of graphite and diamond, and on the ash from some of the samples. The results of these analyses are given in tables 5 and 6 .

TABLE 5.-Results of spectrochemical analyses of diamond and graphites

\begin{tabular}{|c|c|c|}
\hline Sample & Major impurities & Traces \\
\hline $\begin{array}{l}\text { Artificial } \\
\text { Buckingham, untreated } \\
\text { Buckingham, heated to } 1,820^{\circ} \mathrm{C} \text { in vacuo.- } \\
\text { Ceylon, untreated.... } \\
\text { First sample of diamond, untreated }\end{array}$ & 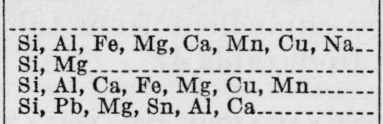 & $\begin{array}{l}\mathrm{Si}, \mathrm{Mg}, \mathrm{Cu} . \\
\mathrm{Hg}, \mathrm{Pb} . \\
\mathrm{Hg}, \mathrm{Sn}, \mathrm{Fe}, \mathrm{Cu} . \\
\mathrm{Na}, \mathrm{Pb}, \mathrm{Ni}, \mathrm{Ag}, \mathrm{Hg} . \\
\mathrm{Fe}, \mathrm{B} .\end{array}$ \\
\hline
\end{tabular}

TABLE 6.-Results of spectrochemical analyses of samples of ash

\begin{tabular}{|c|c|c|c|}
\hline Carbon sample & Major constituents & Minor constituents & Traces \\
\hline $\begin{array}{l}\text { Buckingham, untreated....... } \\
\text { Ceylon, untreated } \\
\text { Ceylon, heated to } 1,750^{\circ} \mathrm{C} . \\
\text { Diamond, untreated............ }\end{array}$ & $\begin{array}{l}\mathrm{Si}, \mathrm{Ca}, \mathrm{Al}, \mathrm{Fe} \\
\mathrm{Si}, \mathrm{Ca}, \mathrm{Fe} \\
\mathrm{Fe} \\
\mathrm{Si}, \mathrm{Cu}, \mathrm{Al} \\
\end{array}$ & $\begin{array}{l}\text { Mn, V, Mg. } \\
\text { Mn, Ai, Mg } \\
\mathrm{Si}, \mathrm{Ca}, \mathrm{V}, \mathrm{Mn}, \mathrm{Mg} \\
\mathrm{Pb}, \mathrm{Ni}, \mathrm{Sn}, \mathrm{Ti}, \mathrm{Fe}, \mathrm{Cr}, \mathrm{Zr} \text {, } \\
\text { Ba, Sr, Mg. }\end{array}$ & $\begin{array}{l}\mathrm{Sr}, \mathrm{Ba}, \mathrm{Ti} . \\
\text { Sr, Cr, Ni. } \\
\text { Al, Ba, Ti, Cr } \\
\text { V, Mn. }\end{array}$ \\
\hline
\end{tabular}

\section{CEYLON NATURAL GRAPHITE}

The results obtained on this sample are shown in table 7 , which is largely self-explanatory. The values used for the energy equivalent of the calorimeter are for the initial calorimetric system, including the oxygen and the charge of carbon, at the mean temperature of the experiment. The values of heat of combustion are therefore referred to the final temperature of the calorimeter, which was sufficiently near to $30^{\circ} \mathrm{C}$ in all experiments so that the correction to $30.00^{\circ} \mathrm{C}$ was negligible. The observed values of heat of combustion under the conditions of the bomb process, $-\Delta U_{B}$, were reduced to the energy change, $-\Delta U_{R}$, for the reaction at $30^{\circ} \mathrm{C}$ and a pressure of 1 atmosphere by means of Washburn's complete correction equation [13], modified so as to apply to $30^{\circ} \mathrm{C}$ instead of $20^{\circ} \mathrm{C}$. The Washburn correction for carbon at $30^{\circ} \mathrm{C}$ is about 9 percent smaller than at $20^{\circ} \mathrm{C}$. The first six measurements listed in table 7 were made on a sample of Ceylon graphite which had received no treatment except grinding in an agate mortar. The value of $-\Delta U_{R}$ from these experiments is seen to be even lower than (although roughly the same as) the value obtained by Dewey and Harper [2] for the Ceylon graphite. Dewey and Harper heated their sample of Ceylon graphite to $225^{\circ} \mathrm{C}$ in vacuo, and it seemed possible that this heating might be the cause of the difference between their value for Ceylon graphite and that obtained from the first six experiments listed in table 7. To test this hypothesis samples of Ceylon graphite were heated in vacuo in an Acheson graphite crucible by means of an induction furnace to various temperatures ranging from $850^{\circ}$ to $1,750^{\circ} \mathrm{C}$, and a few measurements were made of the heat of combustion of each sample. It will be seen from table 7 that heating the graphite to $850^{\circ} \mathrm{C}$ caused an increase in apparent heat of combustion of 0.25 percent, that heating to $900^{\circ}$ or $1,200^{\circ} \mathrm{C}$ caused a further increase of about 0.06 percent, while heating

${ }_{6}$ The spectrochemical analyses were made by B. F. Scribner of this Bureau. 
to $1,750^{\circ} \mathrm{C}$ caused a decrease of about 0.07 percent from the value observed after heating to $1,200^{\circ} \mathrm{C}$. It was also observed that after heating to $1,750^{\circ} \mathrm{C}$ the ash content of the sample had decreased from its initial value, 1.50 percent, to 0.06 percent. This suggested that the initial low value for the heat of combustion of the Ceylon graphite, and the changes in heat of combustion upon heating to various temperatures were caused by chemical reactions involving the impurities in the sample. Carbonates, for example, would be decomposed when the graphite was burned in the bomb, resulting in a low value for the observed heat of combustion of the graphite, while carbides, if they burned, would cause the observed heat of combustion to be too high. However, since it has been suggested by Roth $[10,11,12]$ that there may be two forms of graphite, there was a possibility that the changes in observed heat of combustion of the Ceylon graphite upon heating might have been at least partly the result of a transformation from one form to the other caused by the heating. In order to determine whether the changes in heat of combustion resulted from reactions involving the impurities, or from a change in the structure of the graphite, a sample of Ceylon graphite which had not been heated was purified by treatment with hydrochloric and hydrofluoric acids, and was then heated in vacuo to about $200^{\circ} \mathrm{C}$ to remove traces of the acids and of water. After this treatment, the ash content of the sample was found to be 0.02 percent. The results of four measurements of the heat of combustion of the chemically purified material are given in table 7 (experiments 17 to 20 , inclusive). A part of the chemically purified sample was then heated in vacuo to $1,820^{\circ} \mathrm{C}$, and four measurements were made of the heat of combustion of the material after heating (experiments 21 to 24 , table 7 ). It will be seen from table 7 that the results of the measurements on the sample purified by heating, the sample purified chemically and not heated above $200^{\circ} \mathrm{C}$, and the sample purified chemically and subsequently heated to $1,820^{\circ} \mathrm{C}$ are in agreement within the uncertainty of the measurements. This indicates that the initial low value for the heat of combustion of the Ceylon graphite, and the changes in heat of combustion upon heating to various temperatures were the result of reactions involving the impurities in the sample, rather than the result of a transformation from one form of graphite to another. 
TABLE 7.-Results on Ceylon natural graphite

\begin{tabular}{|c|c|c|c|c|c|c|c|c|c|}
\hline $\begin{array}{l}\text { Experi- } \\
\text { ment a }\end{array}$ & $\begin{array}{l}\text { Carbon } \\
\text { dioxide } \\
\text { formed }\end{array}$ & $\begin{array}{c}\text { Initial } \\
\text { oxy- } \\
\text { gen } \\
\text { pres- } \\
\text { sure } \\
\text { at } \\
30^{\circ} \mathrm{C}\end{array}$ & $\begin{array}{c}\text { Final } \\
\text { tem- } \\
\text { pera- } \\
\text { ture } \\
\text { of } \\
\text { calo- } \\
\text { rime- } \\
\text { ter }\end{array}$ & $\begin{array}{c}\text { Ob- } \\
\text { served } \\
\text { heat of } \\
\text { com- } \\
\text { bus- } \\
\text { tion } \\
-\Delta U_{B}\end{array}$ & $\begin{array}{l}\text { Wash- } \\
\text { burn } \\
\text { correc- } \\
\text { tion }\end{array}$ & $\begin{array}{c}-\Delta U_{R} \\
\text { at } \\
30^{\circ} \mathrm{C}\end{array}$ & & & Remarks \\
\hline $\begin{array}{l}A 5 \\
B 6\end{array}$ & $\begin{array}{c}\text { Moles } \\
0.082053 \\
.082490 \\
.082175 \\
.081876 \\
.088970 \\
.081787\end{array}$ & \begin{tabular}{r|} 
atm \\
34.4 \\
34.4 \\
34.8 \\
33.6 \\
33.5 \\
34.2
\end{tabular} & \begin{tabular}{|l|}
${ }^{\circ} \mathrm{C}$ \\
29.38 \\
29.62 \\
29.86 \\
29.97 \\
30.02 \\
29.83
\end{tabular} & $\begin{array}{c}\text { Int. } \\
\text { kj/mole } \\
392.569 \\
392.994 \\
392.878 \\
392.874 \\
392.807 \\
392.933\end{array}$ & $\begin{array}{c}\text { Int. } \\
\text { kj/mole } \\
-0.392 \\
-.392 \\
-.396 \\
-.384 \\
-.387 \\
-.390\end{array}$ & \begin{tabular}{|c|} 
Int. \\
kj/mole \\
392.177 \\
392.602 \\
392.482 \\
392.490 \\
392.420 \\
392.543
\end{tabular} & $\begin{array}{c}\text { Int. } \\
\text { kj/mole } \\
-0.275 \\
+.150 \\
+.030 \\
+.038 \\
-.032 \\
+.091\end{array}$ & $\begin{array}{r}\text { Percent } \\
-0.070 \\
+.038 \\
+.008 \\
+.010 \\
-.008 \\
+.023\end{array}$ & \multirow{4}{*}{$\begin{array}{l}\text { Sample was ground in } \\
\text { an agate mortar and } \\
\text { burned without further } \\
\text { treatment. Ash } 1.50 \\
\text { percent. } \\
\text { Heated in vacuo to about } \\
900^{\circ} \mathrm{C} \text { for } 3 \text { hours. }\end{array}$} \\
\hline Mer & & $\cdots$ & $\ldots$ & - & 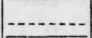 & 392.452 & \pm 0.103 & \pm 0.026 & \\
\hline $\begin{array}{l}B 7 .- \\
B 8 .-\end{array}$ & $\begin{array}{r}0.083484 \\
.083470\end{array}$ & $\begin{array}{l}34.1 \\
34.0\end{array}$ & $\begin{array}{r}30.03 \\
29.57\end{array}$ & $\begin{array}{l}393.992 \\
394.058\end{array}$ & $\begin{array}{r}-0.389 \\
-.389 \\
\end{array}$ & $\begin{array}{l}393.603 \\
393.669\end{array}$ & $\begin{array}{r}-0.033 \\
+.033\end{array}$ & $\begin{array}{r}-0.008 \\
+.008\end{array}$ & \\
\hline Mea & -- & $\ldots$ & -....... & - & - & 393. 639 & \pm 0.033 & \pm 0.008 & \\
\hline $\begin{array}{l}B 9 . .- \\
B 10 . .\end{array}$ & $\begin{array}{r}0.085105 \\
.085876 \\
\end{array}$ & $\begin{array}{l}33.6 \\
33.9\end{array}$ & $\begin{array}{l}30.02 \\
30.13 \\
\end{array}$ & $\begin{array}{l}393.808 \\
393.844\end{array}$ & $\begin{array}{r}-0.386 \\
-.390\end{array}$ & $\begin{array}{l}393.422 \\
393.454\end{array}$ & $\begin{array}{r}-0.016 \\
+.016\end{array}$ & $\begin{array}{r}-0.004 \\
+.004\end{array}$ & \multirow[t]{2}{*}{$\begin{array}{l}\text { Heated in vacuo to about } \\
850^{\circ} \mathrm{C} \text { for } 18 \text { hours. }\end{array}$} \\
\hline $\mathrm{M}$ & $=$ & $\ldots$ & $\ldots$ & 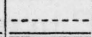 & $\ldots$ & 393.438 & \pm 0.016 & \pm 0.004 & \\
\hline $\begin{array}{l}B 11 \\
B 12\end{array}$ & $\begin{array}{r}0.083211 \\
.083523 \\
\end{array}$ & $\begin{array}{r}34.0 \\
33.9 \\
\end{array}$ & $\begin{array}{l}29.94 \\
29.90\end{array}$ & $\begin{array}{l}393.954 \\
394.172\end{array}$ & $\begin{array}{r}-0.389 \\
-.388 \\
\end{array}$ & $\begin{array}{l}393.565 \\
393.784\end{array}$ & $\begin{array}{r}-0.111 \\
+.110 \\
\end{array}$ & $\begin{array}{r}-0.028 \\
+.028\end{array}$ & \multirow[t]{2}{*}{$\begin{array}{l}\text { Heated in vacuo to about } \\
1,200^{\circ} \mathrm{C} \text { for } 3 \text { hours. }\end{array}$} \\
\hline M & -........ & $\cdots$ & $\ldots$ & $\ldots$ & -......... & 393.674 & \pm 0.110 & \pm 0.028 & \\
\hline $\begin{array}{l}B 13 . \\
B 14 \\
B 15 \\
B 16 .\end{array}$ & $\begin{array}{r}0.083620 \\
.083936 \\
.084979 \\
.083573\end{array}$ & $\begin{array}{l}33.5 \\
34.0 \\
34.0 \\
33.7\end{array}$ & $\begin{array}{l}30.11 \\
29.90 \\
29.89 \\
29.81\end{array}$ & $\begin{array}{l}393.858 \\
393.808 \\
393.728 \\
393.764\end{array}$ & $\begin{array}{r}-0.384 \\
-.389 \\
-.390 \\
-.386\end{array}$ & \begin{tabular}{|l}
393.474 \\
393.419 \\
393.338 \\
393.378
\end{tabular} & $\begin{array}{r}+0.072 \\
+.017 \\
-.064 \\
-.028\end{array}$ & $\begin{array}{r}+0.018 \\
+.004 \\
-.016 \\
-.007\end{array}$ & \multirow[t]{2}{*}{$\begin{array}{l}\text { Heated in vacuo to } 1,750^{\circ} \\
\mathrm{C} \text { for } 11 / 4 \text { hours. Ash } \\
0.06 \text { percent. }\end{array}$} \\
\hline Mea & $-\cdots$ & $\ldots$ & $\ldots$ & -1 & - & 393.402 & \pm 0.045 & \pm 0.011 & \\
\hline $\begin{array}{l}C 17 . \\
C 18- \\
C 19 . \\
C 20\end{array}$ & $\begin{array}{r}0.085399 \\
-083397 \\
.085257 \\
.082830\end{array}$ & $\begin{array}{l}34.0 \\
34.1 \\
34.0 \\
33.9\end{array}$ & $\begin{array}{l}30.11 \\
30.06 \\
30.11 \\
30.16\end{array}$ & $\begin{array}{l}393.769 \\
393.739 \\
393.799 \\
393.829 \\
\end{array}$ & $\begin{array}{r}-0.390 \\
-.390 \\
-.390 \\
-.388\end{array}$ & \begin{tabular}{|l|}
393.379 \\
393.349 \\
393.409 \\
$\mathbf{3} 93.441$ \\
\end{tabular} & $\begin{array}{r}-0.015 \\
-.045 \\
+.015 \\
+.047\end{array}$ & $\begin{array}{r}-0.004 \\
-.012 \\
+.004 \\
+.012\end{array}$ & \multirow{4}{*}{$\begin{array}{l}\text { Purified by treatment } \\
\text { with HCl and HF. } \\
\text { Traces of acids and } \\
\text { moisture were removed } \\
\text { by heating in vacuo to } \\
200^{\circ} \mathrm{C} \text {. Ash } 0.02 \text { per- } \\
\text { cent. } \\
\text { Purified by treatment } \\
\text { with HCl and HF, and } \\
\text { then heated in vacuo to } \\
1,820^{\circ} \mathrm{C} \text { for } 11 / 4 \text { hours. }\end{array}$} \\
\hline & & & 1 & & & 393.394 & \pm 0.030 & \pm 0.008 & \\
\hline $\begin{array}{l}C 21 \\
C 22 \\
C 23 \\
C 24\end{array}$ & $\begin{array}{r}0.082865 \\
-.083031 \\
-.083238 \\
-.084767\end{array}$ & $\begin{array}{l}34.3 \\
34.3 \\
34.0 \\
34.1\end{array}$ & \begin{tabular}{|l|}
30.04 \\
30.09 \\
30.12 \\
30.10
\end{tabular} & $\begin{array}{l}393.634 \\
393.648 \\
393.800 \\
393.778\end{array}$ & $\begin{array}{r}-0.392 \\
-.392 \\
-.389 \\
-.391\end{array}$ & $\begin{array}{l}393.242 \\
393.256 \\
393.411 \\
393.387\end{array}$ & $\begin{array}{r}-0.082 \\
-.068 \\
+.087 \\
+.063\end{array}$ & $\begin{array}{r}-0.021 \\
-.017 \\
+.022 \\
+.016\end{array}$ & \\
\hline & & & & & & 393.324 & \pm 0.075 & \pm 0.019 & \\
\hline
\end{tabular}

a See text, p. 481, for significance of letters preceding experiment numbers.

\section{BUCKINGHAM NATURAL GRAPHITE}

The results of measurements on this sample of graphite are given in table 8. It will be seen that heating to $1,200^{\circ} \mathrm{C}$ caused practically no change in heat of combustion. Heating to $1,820^{\circ} \mathrm{C}$ reduced the ash content of the sample from 0.24 to 0.006 percent, and caused a reduction in heat of combustion of 0.06 percent. The value obtained for the heat of combustion of the purified sample is seen to differ by only 0.015 percent from the mean of the values for the purified samples of Ceylon graphite. 
TABLE 8.-Results on Buckingham natural graphite

\begin{tabular}{|c|c|c|c|c|c|c|c|c|c|}
\hline Experiment & $\begin{array}{l}\text { Carbon } \\
\text { dioxide } \\
\text { formed }\end{array}$ & $\begin{array}{l}\text { Initial } \\
\text { oxygen } \\
\text { pres- } \\
\text { sure at } \\
30^{\circ} \mathrm{C}\end{array}$ & $\begin{array}{l}\text { Final } \\
\text { tem- } \\
\text { pera- } \\
\text { ture of } \\
\text { calo- } \\
\text { rime- } \\
\text { ter }\end{array}$ & $\begin{array}{c}\text { Ob- } \\
\text { served } \\
\text { heat of } \\
\text { com- } \\
\text { bus- } \\
\text { tion } \\
-\Delta U_{B}\end{array}$ & $\begin{array}{l}\text { Wash- } \\
\text { burn } \\
\text { cor- } \\
\text { rection }\end{array}$ & $-\Delta U_{R}$ & \multicolumn{2}{|c|}{$\begin{array}{l}\text { Deviation from } \\
\text { mean }\end{array}$} & Remarks \\
\hline & Moles & $a t m$ & & Int. & Int. & Int. & Int. & rcent & \multirow{4}{*}{$\begin{array}{l}\text { Sample was ground in } \\
\text { an agate mortar and } \\
\text { burned without further } \\
\text { treatment. Ash } 0.24 \\
\text { percent. }\end{array}$} \\
\hline$B 1$. & 0.082913 & 33. 7 & 29.72 & 393.814 & -0.386 & 393.428 & -0.093 & -0.024 & \\
\hline$B 2$. & .084410 & 34.0 & 29.98 & 394.003 & -.389 & 393.614 & +.093 & +.024 & \\
\hline Mean. & & & & & 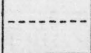 & 393.521 & \pm 0.093 & \pm 0.024 & \\
\hline$B 3$. & 0.083288 & 33.9 & 29.87 & 393.877 & -0.387 & 393.490 & -0.080 & -0.020 & \multirow{4}{*}{$\begin{array}{l}\text { Heated in vacuo to } 1,200^{\circ} \\
\mathbf{C} \text { for } 3 \text { hours. }\end{array}$} \\
\hline$B 4$ & .083700 & 33.7 & 29.74 & 394. 080 & -.385 & 393. 695 & +.125 & +.032 & \\
\hline B5 & .084024 & 34.0 & 29.90 & 393. 914 & -.389 & 393.525 & -.045 & -.011 & \\
\hline Mean & & - & -- & & & 393.570 & \pm 0.083 & \pm 0.021 & \\
\hline$B 6$. & 0.080557 & 33.3 & 29.76 & 393.695 & -0.380 & $\overline{393.315}$ & +0.005 & +0.001 & \multirow{4}{*}{$\begin{array}{l}\text { Heated in vacuo to } 1,820^{\circ} \\
\mathrm{C} \text { for } 11 / 4 \text { hours. Ash } \\
0.006 \text { percent. }\end{array}$} \\
\hline B7 & .082820 & 33. 2 & 29.83 & 393.720 & -.380 & 393.340 & +.030 & +.008 & \\
\hline$B 8$ & .081344 & 33.1 & 29.94 & 393.654 & -.378 & 393. 276 & -.034 & -.009 & \\
\hline Mean & & & & & & 393. 310 & \pm 0.023 & \pm 0.006 & \\
\hline
\end{tabular}

\section{ARTIFICIAL GRAPHITE}

The results of measurements on two samples of this material are listed separately in table 9, although there was no reason for believing that there was any difference between the two samples. In experiments $3,4,5$, and 6 on the first sample about $5 \mathrm{mg}$ of benzoic acid was used to start the combustion, the electric fuse being placed in contact with the benzoic acid and not in contact with the graphite. The purpose of these experiments was to determine whether any error resulted from conduction of electricity through the powdered graphite in the usual method of igniting the sample. The results for experiments $3,4,5$, and 6 are in agreement within the limits of experimental error with the other results on the artificial graphite.

TABLE 9.-Results on artificial graphite

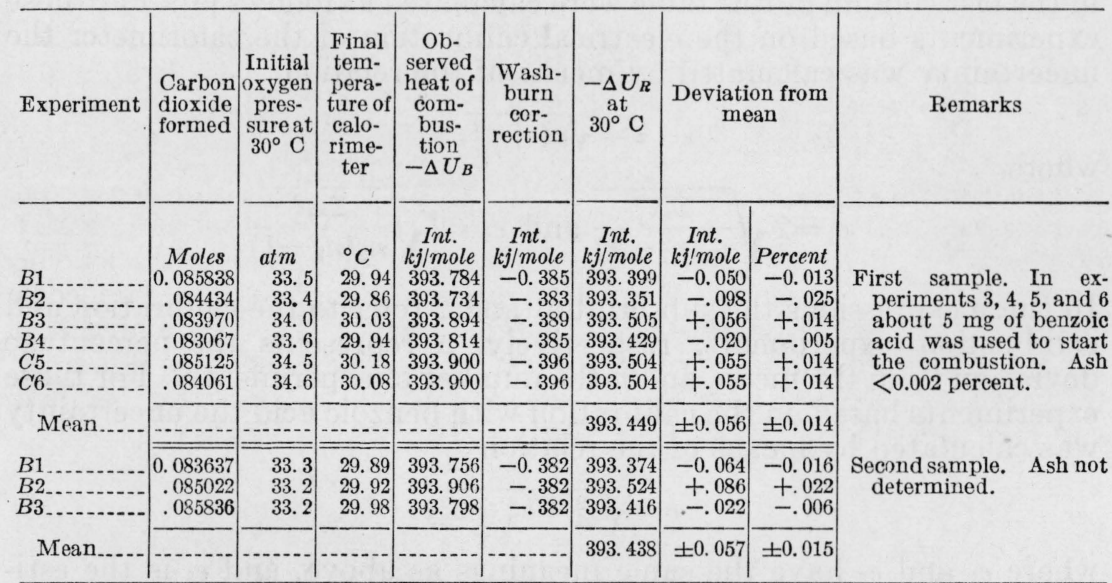




\section{REESUMÉ OF RESULTS ON PURIFIED GRAPHITE}

The results of all the measurements on purified samples of graphite are assembled in table 10.

TABLE 10.-Résumé of results on purified graphite

\begin{tabular}{|c|c|c|c|c|c|c|c|c|}
\hline \multirow{2}{*}{$\begin{array}{c}\begin{array}{c}\text { Sample and method of } \\
\text { purification }\end{array} \\
\\
\text { Ceylon natural graphite } \\
\text { heated in vacuo to } \\
1,750^{\circ} \text { C. Ash } 0.06 \\
\text { percent_............... }\end{array}$} & \multirow{2}{*}{$\begin{array}{l}\begin{array}{c}\text { Experi- } \\
\text { ment }\end{array} \\
\\
\left\{\begin{array}{c}B 13 \\
B 14 \\
B 15 \\
B 16\end{array}\right.\end{array}$} & \multirow{2}{*}{$\begin{array}{c}-\Delta U_{R} \text { at } \\
30^{\circ} \mathrm{C} \\
\\
\text { Int. } k j / m o l e \\
393.474 \\
393.419 \\
393.338 \\
393.378\end{array}$} & \multicolumn{2}{|c|}{$\begin{array}{l}\text { Deviation from } \\
\text { mean of all } \\
\text { observations }\end{array}$} & \multirow{2}{*}{$\begin{array}{c}\begin{array}{c}\text { Mean for } \\
\text { sample } \\
\text { Int. kj/mole } \\
393.402\end{array} \\
390 \\
3\end{array}$} & \multirow{2}{*}{$\begin{array}{c}\begin{array}{c}\text { Uncer- } \\
\text { tainty } \\
\text { of } \\
\text { mean } \\
\text { for } \\
\text { sam- } \\
\text { ple }\end{array} \\
\text { Percent } \\
\pm 0.019\end{array}$} & \multicolumn{2}{|c|}{$\begin{array}{l}\text { Deviation from } \\
\text { mean of all } \\
\text { observations }\end{array}$} \\
\hline & & & $\begin{array}{r}\text { Int. } \mathrm{kj} / \text { mole } \\
+0.081 \\
+.026 \\
-.055 \\
-.015\end{array}$ & $\begin{array}{l}\text { Percent } \\
+0.021 \\
+.007 \\
-.014 \\
-.004\end{array}$ & & & Int. $\mathrm{kj} / \mathrm{mole}$ & $\begin{array}{l}\text { Percent } \\
+0.002\end{array}$ \\
\hline $\begin{array}{l}\text { Ceylon graphite puri- } \\
\text { fied by treatment with } \\
\text { HCl and HF. Ash } \\
0.02 \text { percent............ }\end{array}$ & $\begin{array}{l}C 17 \\
C 18 \\
C 19 \\
C 20\end{array}$ & $\begin{array}{l}393.379 \\
393.349 \\
393.409 \\
393.441\end{array}$ & $\begin{array}{l}-.014 \\
-.044 \\
+.016 \\
+.048\end{array}$ & $\begin{array}{l}-.004 \\
-.011 \\
+.004 \\
+.012\end{array}$ & 393.394 & \pm .026 & +.002 & .001 \\
\hline $\begin{array}{l}\text { Ceylon graphite puri- } \\
\text { fied by treatment with } \\
\mathrm{HCl} \text { and HF. Sam- } \\
\text { ple then heated in } \\
\text { vacuo to } 1,820^{\circ} \mathrm{C} \text {....-. }\end{array}$ & $\begin{array}{l}C 21 \\
C 22 \\
C 23 \\
C 24\end{array}$ & $\begin{array}{l}393.242 \\
393.256 \\
393.411 \\
393.387\end{array}$ & $\begin{array}{l}-.151 \\
-.137 \\
+.018 \\
-.006\end{array}$ & $\begin{array}{r}-.038 \\
-.035 \\
+.005 \\
+.002\end{array}$ & 393.324 & \pm .032 & -.068 & -.017 \\
\hline $\begin{array}{l}\text { Buckingham graphite } \\
\text { heated in vacuo to } \\
1,820^{\circ} \text { C. Ash } 0.006 \\
\text { percent_. A }\end{array}$ & $\begin{array}{l}B 6 \\
B 7 \\
B 8\end{array}$ & $\begin{array}{l}393.315 \\
393.340 \\
393.276\end{array}$ & $\begin{array}{l}-.078 \\
-.053 \\
-.117\end{array}$ & $\begin{array}{l}-.020 \\
-.013 \\
-.030\end{array}$ & 393. 310 & \pm .015 & -.083 & -.021 \\
\hline $\begin{array}{l}\text { Artificial graphite. First } \\
\text { sample. Ash }<0.002 \\
\text { percent. }\end{array}$ & $\begin{array}{l}B 1 \\
B 2 \\
B 3 \\
B 4 \\
C 5 \\
C 6\end{array}$ & $\begin{array}{l}393.399 \\
393.351 \\
393.505 \\
393.429 \\
393.504 \\
393.504\end{array}$ & $\begin{array}{l}+.006 \\
+.042 \\
+.112 \\
+.036 \\
+.111 \\
+.111\end{array}$ & $\begin{array}{l}+.002 \\
+.011 \\
+.028 \\
+.009 \\
+.028 \\
+.028\end{array}$ & 393. 449 & \pm .020 & +.055 & +.014 \\
\hline $\begin{array}{l}\text { Artificial graphite. } \\
\text { Second sample. Ash } \\
\text { not determined. }\end{array}$ & $\begin{array}{l}B 1 \\
B 2 \\
B 3\end{array}$ & $\begin{array}{l}393.374 \\
393.524 \\
393.418 \\
\end{array}$ & $\begin{array}{l}-.019 \\
+.131 \\
+.025\end{array}$ & $\begin{array}{l}-.005 \\
+.033 \\
+.006\end{array}$ & 393.438 & \pm .025 & +.045 & +.011 \\
\hline $\begin{array}{l}\text { Mean of individ- } \\
\text { ual observations. }\end{array}$ & & 393.393 & \pm .060 & \pm .015 & & & \pm .043 & \pm .011 \\
\hline
\end{tabular}

The uncertainties of the mean values for the various samples given in the last column of this table were calculated as follows [9]: For those experiments based on the electrical calibration of the calorimeter the uncertainty was calculated by means of the relation

where

$$
e=\sqrt{e_{1}^{2}+e_{2}^{2}},
$$

$$
e_{1}=2 \sqrt{\frac{\Sigma \Delta_{1}^{2}}{n_{1}\left(n_{1}-1\right)}} \text { and } e_{2}=2 \sqrt{\frac{\Sigma \Delta_{2}^{2}}{n_{2}\left(n_{2}-1\right)}}
$$

In these expressions the subscripts 1 and 2 refer to the calibration and combustion experiments, respectively, $\Delta$ represents the percentage deviation from the mean, and $n$ the number of experiments. For those experiments based on the calibration with benzoic acid the uncertainty was calculated by means of the relation

$$
e=\sqrt{e_{1}^{2}+e_{2}^{2}+e_{3}^{2}},
$$

where $e_{1}$ and $e_{2}$ have the same meanings as above, and $e_{3}$ is the estimated uncertainty ( 0.023 percent) in the value used for the heat of 
combustion of benzoic acid. It will be seen from table 10 that, with the exception of the value for Buckingham natural graphite, the mean value for each sample is in agreement within the calculated uncertainty of that value, with the mean of all the individual results on the purified samples. The average deviation of the individual results from this mean value is 0.015 percent, and the maximum deviation is 0.038 percent. The average deviation of the means for the various samples from the mean of all the results is 0.011 percent, while the maximum deviation of the mean for any one sample is 0.021 percent. The results therefore indicate that the three varieties of graphite are identical, at least so far as their energy content is concerned.

Using the values $8.78,20.82$, and $28.08 \mathrm{j} /$ mole [4] for the specific heats at constant volume of graphite, oxygen, and carbon dioxide, respectively, the value calculated for the temperature coefficient $\left(d\left(-\Delta U_{R}\right) / d T\right)$ of the heat of combustion of graphite is $1.5 \mathrm{j} / \mathrm{mole}{ }^{\circ} \mathrm{C}$. Using this value for the temperature coefficient of $-\Delta U_{R}$ and the mean value of $-\Delta U_{R}$ at $30^{\circ} \mathrm{C}$ from table 10 , the value calculated for $-\Delta U_{R}$ at $25^{\circ} \mathrm{C}$ for the reaction

$$
\mathrm{C} \text { (graphite) }+\mathrm{O}_{2} \text { (gas) }=\mathrm{CO}_{2} \text { (gas) }
$$

is $393.385 \mathrm{int} . \mathrm{kj} / \mathrm{mole}$. The value of $-\Delta(p v)$ for the above reaction calculated by means of the Beattie-Bridgeman equation of state [1] is $0.011 \mathrm{kj}$, so that the value derived from the results of the present work for $-\Delta H=-\Delta U_{R}-\Delta(p v)$ for the above reaction at $25^{\circ} \mathrm{C}$ and a constant pressure of 1 atmosphere is 393.396 int. $\mathrm{kj} / \mathrm{mole}(44.010 \mathrm{~g}$ of carbon dioxide).

\section{DIAMOND}

As the first sample of diamond was very finely powdered, it was thought that there might be an appreciable thermal effect due to adsorption of oxygen. About $5.6 \mathrm{~g}$ of the sample was therefore put in a Pyrex glass tube and evacuated by means of a mercury-vapor pump connected to the tube containing the diamond through a trap immersed in liquid air. The tube containing the diamond was heated to temperatures ranging from $550^{\circ}$ to $575^{\circ} \mathrm{C}$, and the evacuation was continued for several days. Most of the adsorbed gas was removed in this way, as may be seen from the fact that at the end of the first day, with the diamond at a temperature of $570^{\circ} \mathrm{C}$ and with the pump operating, the minimum pressure reached was $0.0035 \mathrm{~mm}$, and when the pump was shut off the pressure rose to $0.13 \mathrm{~mm}$ in 10 minutes, while on the last day of the pumping with the diamond at a temperature of $575^{\circ} \mathrm{C}$, a pressure of $<0.0001 \mathrm{~mm}$ was attained with the pump operating, and when the pump was shut off the pressure rose to only $0.003 \mathrm{~mm}$ in 10 minutes.

After evacuation, the tube containing the diamond was sealed off, immersed in the water of a calorimeter, and after sufficient time had elapsed for the attainment of thermal equilibrium, dry oxygen was admitted to a pressure of 1 atmosphere, and the temperature change of the calorimeter was observed. The evacuation of the diamond was then repeated and a second measurement was made of the thermal effect of adsorption of oxygen. The observed thermal effect in the two experiments was 2.5 and $2.8 \mathrm{j} / \mathrm{g}$ of diamond, or 0.032 $\mathrm{kj} / \mathrm{mole}$. The internal surface of the glass tube which contained 
the diamond in these experiments was only about 0.2 percent of the surface of the diamond itself, so that the effect of adsorption on the surface of the tube was probably negligible and a blank experiment was considered unnecessary. In similar experiments covering the pressure range 1 to 30 atmospheres, no thermal effect due to adsorption of oxygen was observed. As the specific surface of the second sample of diamond was much smaller than that of the first, it was assumed that the thermal effect of adsorption of oxygen on this sample was negligible, and no measurement of the effect was made. The sample was, however, heated in vacuo to about $550^{\circ} \mathrm{C}$ to remove traces of acids used in purifying it.

The results of the heat of combustion measurements on the two samples of diamond are given in tables 11 and 12.

TABLE 11.-Results on first sample of diamond

\begin{tabular}{|c|c|c|c|c|c|c|c|c|}
\hline Experiment & $\begin{array}{l}\text { Carbon } \\
\text { dioxide } \\
\text { formed }\end{array}$ & $\begin{array}{c}\text { Initial } \\
\text { oxygen } \\
\text { pres- } \\
\text { sure } \\
\text { at } \\
30^{\circ} \mathrm{C}\end{array}$ & $\begin{array}{l}\text { Observ- } \\
\text { ed heat } \\
\text { of com- } \\
\text { bustion } \\
\text { at } 30^{\circ} \mathrm{C} \\
-\Delta U_{B}\end{array}$ & $\begin{array}{l}\text { Wash- } \\
\text { burn } \\
\text { correc- } \\
\text { tion }\end{array}$ & at $30^{\circ}{ }^{\circ} \mathrm{C}$ & $\begin{array}{r}\text { Deviat } \\
\mathrm{m}\end{array}$ & $\begin{array}{l}\text { tion from } \\
\text { ean }\end{array}$ & Remarks \\
\hline $\begin{array}{l}C 1 \\
C{ }^{2} \\
C 4 \\
C 5 \\
C 6\end{array}$ & $\begin{array}{c}\text { Moles } \\
0.082878 \\
.083895 \\
.083182 \\
.083308 \\
.083724 \\
.083677 \\
.083556\end{array}$ & $\begin{array}{c}\text { atm } \\
33.5 \\
33.8 \\
33.4 \\
33.9 \\
33.8 \\
33.8 \\
33.9\end{array}$ & $\begin{array}{c}\text { Int. } \\
\text { kjj/mole } \\
395.907 \\
396.115 \\
396.232 \\
396.227 \\
396.327 \\
395.965 \\
395.999\end{array}$ & $\begin{array}{c}\text { Int. } \\
\mathrm{kj} / \mathrm{mole} \\
-0.384 \\
-.387 \\
-.383 \\
-.388 \\
-.387 \\
-.387 \\
-.388\end{array}$ & $\begin{array}{c}\text { Int. } \\
\text { kj/mole } \\
395.523 \\
395.728 \\
395.849 \\
395.839 \\
395.940 \\
395.578 \\
395.611\end{array}$ & $\begin{array}{c}\text { Int. } \\
\text { kj/mole } \\
-0.203 \\
+.004 \\
+.125 \\
+.115 \\
+.216 \\
-.146 \\
-.113\end{array}$ & $\begin{array}{c}\text { Percent } \\
-0.051 \\
+.001 \\
+.032 \\
+.029 \\
+.055 \\
-.037 \\
-.029\end{array}$ & $\begin{array}{l}\text { A verage particle } \\
\text { diameter } 2.5 \mu \\
\text { Ash } 0.05 \text { percent. }\end{array}$ \\
\hline $\begin{array}{l}\text { Mean } \\
\text { Correction for heat of } \\
\text { adsorption of } \mathrm{O}_{2-} \\
\text { Corrected value of } \\
-\Delta U_{R}\end{array}$ & & & & & $\begin{array}{r}395.724 \\
+0.032 \\
395.756\end{array}$ & \pm 0.132 & \pm 0.033 & \\
\hline
\end{tabular}

TABLE 12.-Results on second sample of diamond

\begin{tabular}{|c|c|c|c|c|c|c|c|c|}
\hline Experiment & $\begin{array}{l}\text { Carbon } \\
\text { dioxide } \\
\text { formed }\end{array}$ & $\begin{array}{c}\text { Initial } \\
\text { oxygen } \\
\text { pres- } \\
\text { sure at } \\
30^{\circ} \mathrm{C}\end{array}$ & $\begin{array}{c}\text { Ob- } \\
\text { served } \\
\text { heat of } \\
\text { com- } \\
\text { bustion } \\
\text { at } 30^{\circ} \mathrm{C} \\
-\Delta U_{B}\end{array}$ & $\begin{array}{c}\text { Wash- } \\
\text { burn } \\
\text { correc- } \\
\text { tion }\end{array}$ & $\begin{array}{r}-\Delta U_{R} \\
\text { at } 30^{\circ} \mathrm{C}\end{array}$ & \multicolumn{2}{|c|}{$\begin{array}{l}\text { Deviation from } \\
\text { mean }\end{array}$} & Remarks \\
\hline $\begin{array}{l}C 1 \\
C 2 \\
C 4\end{array}$ & $\begin{array}{c}\text { Moles } \\
0.083133 \\
.083424 \\
.083206 \\
.083376 \\
.083230 \\
.084311\end{array}$ & $\begin{array}{l}\text { atm } \\
34.0 \\
34.0 \\
34.0 \\
34.3 \\
34.3 \\
34.0\end{array}$ & $\begin{array}{c}\text { Int. } \\
\text { kj/mole } \\
395.720 \\
395.566 \\
395.550 \\
395.696 \\
395.588 \\
395.754\end{array}$ & $\begin{array}{c}\text { Int. } \\
k j / \text { mole } \\
-0.389 \\
-.389 \\
-.389 \\
-.392 \\
-.392 \\
-.389\end{array}$ & $\begin{array}{c}\text { Int. } \\
k j / \text { mole } \\
395.331 \\
395.177 \\
395.161 \\
395.304 \\
395.196 \\
395.365\end{array}$ & \begin{tabular}{c} 
Int. \\
$k j /$ mole \\
+0.075 \\
-.079 \\
-.095 \\
+.048 \\
\hdashline .060 \\
+.109
\end{tabular} & $\begin{array}{c}\text { Per- } \\
\text { cent } \\
+0.019 \\
-.020 \\
-.024 \\
+.012 \\
.015 \\
+.028\end{array}$ & $\begin{array}{l}\text { A verage particle } \\
\text { diameter } 39.5 \mu \text {. } \\
\text { Ash } 0.02 \text { percent. }\end{array}$ \\
\hline Mea & - & $\ldots$ & -......... & -........ & 395.256 & \pm 0.078 & \pm 0.020 & \\
\hline C7 8 - & $\begin{array}{r}0.074524 \\
.074897 \\
\end{array}$ & $\begin{array}{l}34.5 \\
34.2\end{array}$ & $\begin{array}{l}395.788 \\
395.627\end{array}$ & $\begin{array}{l}-0.387 \\
-.385\end{array}$ & $\begin{array}{l}395.401 \\
395.242\end{array}$ & $\begin{array}{r}+0.079 \\
-.080\end{array}$ & $\begin{array}{r}+0.020 \\
-.020\end{array}$ & $\begin{array}{l}\text { Average particle } \\
\text { diameter } 22.9 \mu .\end{array}$ \\
\hline $\begin{array}{l}\text { Mean } \\
\text { Mean of all results on } \\
\text { second sample.... }\end{array}$ & & $\ldots$ & & - & $\begin{array}{l}395.322 \\
395.272\end{array}$ & \pm 0.080 & \pm 0.020 & \\
\hline
\end{tabular}

It will be seen from these tables that the mean value of $-\Delta U_{R}$ for the first sample, when corrected for the thermal effect of adsorption of oxygen, is higher by $0.500 \mathrm{kj} / \mathrm{mole}$, or 0.13 percent, than the value 
for the coarser fraction of the second sample; and that the value for the finer fraction of the second sample is higher by $0.066 \mathrm{kj} / \mathrm{mole}$, or 0.017 percent, than that for the coarser fraction. This last difference is within the uncertainty of the measurements.

The difference between the observed heats of combustion of the two samples is in the direction to be expected from the relative sizes of the particles, but is greater than the difference obtained by a rough calculation of the effect of particle size. This calculation was based on the assumption that the energy content of the finer sample of diamond was greater than that of macrocrystalline diamond as a result of unsaturated bonds at the surface. In making the calculation it was assumed that the carbon-carbon bond energy in diamond is 70 $\mathrm{kcal} / \mathrm{mole}$, so that the corresponding surface energy is $35 \mathrm{kcal}$ per $N$ unsaturated bonds, or $70 \mathrm{kcal}$ per $N$ surface atoms, where $N$ is Avogadro's number. The surface energy of the finer sample calculated in this manner is about 25 percent of the difference between the observed heats of combustion of the two samples of diamond.

It has been reported by Robertson, Fox, and Martin [7] that there are two types of diamond which differ in a number of physical properties, and it is conceivable that one of the samples in the present work consisted largely of one of these types, while the other sample consisted largely of the other type of diamond. This is extremely unlikely, however, because of the comparative rarity of one of the types. Robertson, Fox, and Martin found one specimen of the rarer type by accident, and then examined between 200 and 300 other diamonds before finding a second specimen of the rarer type. Also, it seems unlikely that the difference between the heats of combustion of the two types of diamond could be as great as 25 percent of the difference between the heats of combustion of graphite and diamond. In this connection it may be noted that Robertson, Fox, and Martin found that the two types of diamond did not differ appreciably in a number of properties including density, specific heat, refractive index, dielectric constant, and the arrangement of the atoms in the crystal lattice.

Since the difference between the two sets of data in tables 11 and 12 has not been explained there is considerable uncertainty as to the value of the heat of combustion of diamond. Because of the possibility of surface effects other than the one considered above, it is believed that the mean value of $-\Delta U_{R}$ from the eight experiments on the second sample of diamond, namely $395.272 \mathrm{int} . \mathrm{kj} / \mathrm{mole}$, is as good a value for $-\Delta U_{R}$ at $30^{\circ} \mathrm{C}$ for the combustion of macrocrystalline diamond as can be derived from the results of the present investigation. The change in this value by reduction to $25^{\circ} \mathrm{C}$ is +0.004 $\mathrm{kj} / \mathrm{mole}$. The corresponding value of $-\Delta H$ for the reaction

$$
\mathrm{C} \text { (diamond) }+\mathrm{O}_{2} \text { (gas) }=\mathrm{CO}_{2} \text { (gas) }
$$

is $395.287 \mathrm{int} . \mathrm{kj} / \mathrm{mole}\left(44.010 \mathrm{~g}\right.$ of carbon dioxide) at $25^{\circ} \mathrm{C}$ and a constant pressure of 1 atmosphere. The uncertainty in this value, calculated as described previously, is 0.029 percent, while the calculated uncertainty of the mean result for the first sample of diamond is 0.038 percent. 
In conclusion, the author gratefully acknowledges his indebtedness to numerous members of the bureau staff who have cooperated in this work. Especial credit is due F. D. Rossini who has been much interested in this investigation, and who has given much valuable advice throughout the course of the work. The author is also grateful to H. H. Lowry for the samples of graphite, and to P. E. Verkade for his assistance in obtaining one of the samples of diamond.

\section{REFERENCES}

[1] James A. Beattie and Oscar C. Bridgeman, Proc. Am. Acad. Arts and Sci. 63, 229 (1928).

[2] Phillip H. Dewey and D. Roberts Harper, 3d, J. Research NBS 21, 457 (1938) RP1139.

[3] Hobert C. Dickinson, Bul. BS 11, 189 (1914) S230.

[4] Int. Crit. Tables 5, 94 (1928).

[5] Ralph S. Jessup, J. Research NBS 18, 115 (1937) RP966.

[6] Ralph S. Jessup and Carleton B. Green, J. Research NBS 13, 469 (1934) RP721.

[7] Robert Robertson, J. J. Fox, and A. E. Martin, Phil. Trans. Roy. Soc. (London) [A] 232, 463 (1934); Proc. Roy. Soc. (London) [A] 15\%, 579 (1936).

[8] Frederick D. Rossini, BS J. Research 6, 37 (1931) RP260.

[9] Frederick D. Rossini. Chem. Rev. 18, 233 (1936).

[10] W. A. Roth and H. Wallasch, Ber. deut. chem. Ges. 46, 896 (1913).

[11] W. A. Roth and H. Wallasch, Z. Elektrochem. 21, 1 (1915).

[12] W. A. Roth and W. Naeser, Z. Elektrochem. 31, 461 (1925).

[13] Edward W. Washburn, BS J. Research 10, 525 (1933) RP546.

Washington, July 15, 1938. 